International Research Journal of Management, IT \& Social Sciences
Available online at https://sloap.org/journals/index.php/irjmis/
Vol. 8 No. 1, January 2021, pages: 102-109
ISSN: 2395-7492
http://dx.doi.org/10.21744/irjmis.v0i0.000

\title{
Corporate Governance and Political Connection towards the Tax Aggressiveness of Manufacturing Companies in Indonesia
}

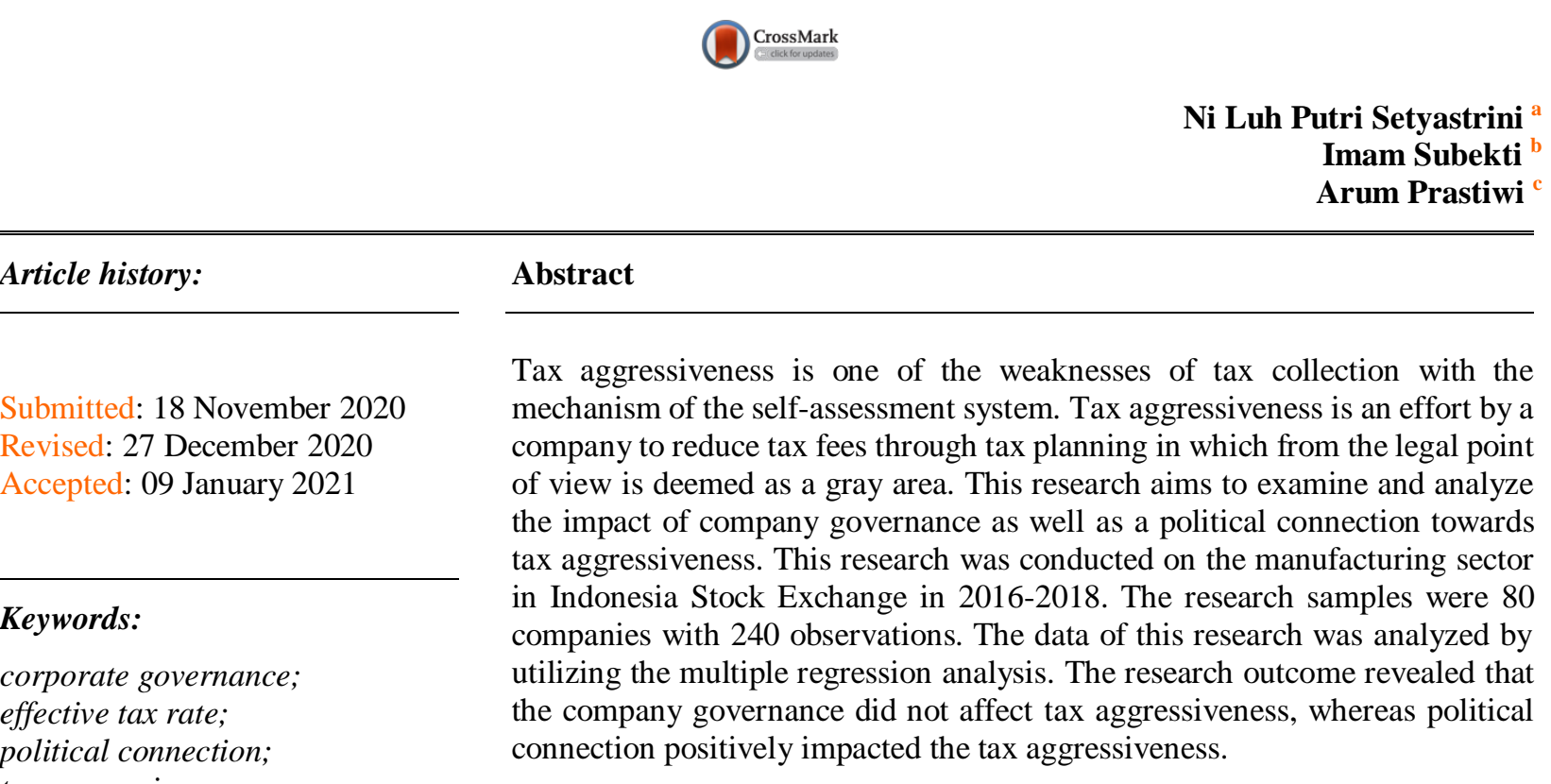

International research journal of management, IT and social sciences (C) 2021. This is an open access article under the CC BY-NC-ND license (https://creativecommons.org/licenses/by-nc-nd/4.0/).

\section{Corresponding author:}

Ni Luh Putri Setyastrini,

Accounting Department, Brawijaya University, Indonesia.

Email address: putrisetyastrini@gmail.com

\footnotetext{
Accounting Department, Brawijaya University, Indonesia Accounting Department, Brawijaya University, Indonesia Accounting Department, Brawijaya University, Indonesia 


\section{Introduction}

Tax aggressiveness is an action that is detrimental to the Indonesian government. Tax aggressiveness is the measure to reduce tax fees carried out by companies as they believe that tax payments bring a negative effect to the company's cash flow (Richardson et al., 2014). Tax aggressiveness is one of the weaknesses of the implementation of the selfassessment system in the taxation process in Indonesia (Bawazier, 2018). Study results from the Tax Justice Network (TJN) showed that tax aggressiveness is detrimental to the global economy every year of up to Rp 6,046 Trillion (CNN, 2020). A reputable tobacco company in Indonesia namely PT Bentoel International Investama Tbk which is owned by British American Tobacco has been alleged of carrying out tax avoidance that caused grave losses for Indonesia amounting to US\$ 14 million per year (Kartika, 2019).

Such tax aggressiveness conducted by the company could be affected by several factors namely diversification of types of company (Zheng, 2017), characteristics of the company (Gupta \& Newberry, 1997), political connections (Adhikari et al., 2006), corporate governance (Desai \& Dharmapala, 2006; Ramantha, 2020) or even corporate social responsibility (Landry et al., 2013). Tax aggressiveness is one of the forms of agency conflict type III between companies as internal parties and the government (tax authority) that is part of the company's external parties (Armour et al., 2009). Corporate governance is believed to be one of the solutions to minimize the company's agency conflict. The implementation of corporate governance could minimize the company's tax aggressiveness (Chan et al., 2013). Other research showed the opposite results that corporate governance has not been able to prevent companies to carry out tax aggressiveness (Wahab \& Holland, 2012).

The political connection is a prominent resource for companies (Fisman, 2001). Companies that have political connections tend to not carry out precarious actions such as tax aggressiveness as it could affect the company's reputation (Zhang et al., 2012). Rather, companies with political connections are more likely to utilize the political connection they have to gain profit for the company (Kim \& Zhang, 2016). Previous research that was not consistent has led the researchers to re-examine the impact of a corporate company and political connection towards tax aggressiveness. This research will assess the implementation of corporate governance referring to Circular Letter of The Financial Services Authority Number 32/SEOJK.04/2015 concerning Public Companies' Corporate Governance Guidelines. The measurement refers to the Circular Letter of the Financial Services Authority as the mechanism of the conventional governance is deemed not strong enough to solve agency problems in Asia (Claessens et al., 2002). This research will assess the company's political connections as referred to in the research by Sutrisno et al. (2019), which assesses the political connections based on the structural government positions who are Civil Servants (Pegawai Negeri Sipil) (PNS) in Indonesia.

\section{Literature review and hypothesis development}

\section{Agency theory}

The agency theory explicates a contract between one or more parties (principals) that involve other parties (agents) to perform certain actions on behalf of the principal as well as to delegate decision-making authority to the agents (Jensen \& Meckling, 1976). The delegation of authority towards the agent would cause agency conflicts in the company. The agency conflict is not only related to the conflict between owners (principals) and managers (agents), but it could also be concerning the conflict of majority-minority as well as corporate conflicts with the company's external parties (Armour et al., 2009). Tax aggressiveness is an agency conflict that occurs between a company and the company's external party namely the government (tax authority). The efforts to minimize the agency conflict between the company and the tax authority could be carried through the implementation of corporate governance as well as to create political connections.

\section{Corporate Governance}

Organization for Economic Cooperation and Development (OECD, 2015) defines corporate governance as a procedure and process relating to the implementation and supervision of the company. Corporate governance could elaborate on the distribution of rights and responsibilities of the parties involved in the company.

Setyastrini, N. L. P., Subekti, I., \& Prastiwi, A. (2021). Corporate governance and political connection towards the tax aggressiveness of manufacturing companies in Indonesia. International Research Journal of Management, 


\section{Political Connection}

Companies that are linked with politics is defined as companies with one of the majority shareholders or top executive positions of the company which is (a) members of parliament, (b) ministers or head of states, or (c) have close ties with high-ranked officials (Faccio, 2006). Companies owned by the state or state-owned enterprises could also be classified as companies with political connections (Wong \& Hooy, 2018).

\section{Tax aggressiveness}

Tax aggressiveness is an action carried by companies to manipulate taxable profit by displaying lower taxable profit through tax planning but could not be deemed as an act of tax evasion (Frank et al., 2009) or in legal aspect is in the gray area (Lietz, 2013). Tax aggressiveness is performed by companies as they believe that tax payment negatively affects their financial position, financial performance, liquidity, operational result as well as the cash flow of the company (Richardson et al., 2014).

\section{Corporate governance and tax aggressiveness}

Tax aggressiveness is one of the agency conflicts that occur between the company and tax authority. Corporate governance is believed as one of the solutions to minimize agency conflicts. The implementation of corporate governance is believed to bolster the supervision of the internal and external parties as well as the government (Kim et al., 2010). Optimal supervision from such parties would prevent the company to perform tax aggressiveness (Mahenthrian \& Kasipillai, 2012; Taylor \& Richardson, 2013). Based on prior presentations and research, the proposed hypothesis is:

\section{H1: Corporate governance has a negative impact on tax aggressiveness}

\section{Political connection and tax aggressiveness}

Companies with political connections receive benefits as well as obtain more optimal supervision from the government (Lestari \& Putri, 2017). Companies with political connections tend to maintain their company reputation so that it would not carry out any precarious actions such as tax aggressiveness (Anggraeni, 2018). Political connections possessed by companies is believed to create corporate compliance towards tax regulations and to avoid tax aggressiveness (Wicaksono, 2017). Based on the prior presentations and research, the proposed hypothesis is:

H2: Political connections have a negative impact on tax aggressiveness

\section{Materials and Methods}

This research utilizes the quantity approach of explanatory research in the form of associative research. The population from this research is the manufacturing companies in 2016-2018 with the sample criteria as well the sample amount obtained is presented in Table 1. The dependent variable namely the tax aggressiveness in this research is measured with the effective tax rate (ETR) which divides the current tax fees with the profit before tax. Companies with high ETR values indicate they do not perform tax aggressiveness.

The independent variable namely the corporate governance is measured by dividing the number of recommendations that have been implemented by the company with the total number of recommendations $(25$ recommendations) according to SE OJK Number 32/SEOJK.04/2015. The political connection is measured with the LN formula LN (1+IKP) namely IKP is a score for political connection possessed by a company following the research by Sutrisno et al. (2019). The control variable in this research is the profitability (after-tax profit divided by the total $\operatorname{asset}_{(\mathrm{t}-1)}$, company's fixed assets (net asset value divided by the total asset) as well as company size (LN total asset). 
Table 1

Procedure for sample selection

\begin{tabular}{clc}
\hline No & \multicolumn{1}{c}{ Criteria } & Amount \\
\hline 1 & Manufacturing companies registered in Indonesia Stock Exchange (BEI) & 144 \\
2 & consecutively as per 2016 until 2018 & $(4)$ \\
3 & Companies not publishing their annual report consecutively as per 2016-2018 & $(50)$ \\
4 & Companies nompany operating profit & $(2)$ \\
5 & Effective Tax Rate (ETR) Value $>1$ & $(8)$ \\
Number of companies as research samples & 80 \\
Number of observations for 3 years (2016-2018) & 240 \\
\hline
\end{tabular}

\section{Results and Discussions}

\section{Descriptive statistical results}

The descriptive statistics in this research present the general view regarding the data being observed namely the minimum, maximum, average as well as standard deviation.

Table 2

Descriptive statistics

\begin{tabular}{lllll}
\hline & Min & Max & Mean & Std. Deviation \\
\hline Tax Aggressiveness (ETR) & 0.000 & 0.924 & 0.254 & 0.109 \\
Corporate Governance (CG) & 0.280 & 1.000 & 0.703 & 0.237 \\
Political Connection (PC) & 0.000 & 3.784 & 1.085 & 1.194 \\
Profitability (ROA) & 0.001 & 0.581 & 0.089 & 0.087 \\
Fixed Assets (PPE) & 0.040 & 1.187 & 0.460 & 1.171 \\
Company Size (SIZE) & 25.216 & 33.474 & 28.799 & 1.661 \\
\hline
\end{tabular}

\section{Hypothesis testing}

The data from this research is analyzed by utilizing the multiple linear regression analysis. The regression model in this research has fulfilled the classical assumption test namely normality test, heteroscedasticity as well as multicollinearity. The regression result of this research is presented in Table 3. Based on Table 3, this research has the value of adjusted $R^{2}$ amounting to 0.093 . Such a number means that the variable in the model could affect the tax aggressiveness amounting to $9.3 \%$ as well as for the rest, they are influenced by other variables that are not included in the research model. Test $\mathrm{F}$ aims to examine the model conformity as well as to observe whether there is an independent variable or not that influences the dependent variables. Test F of this research has the value of sig ANOVA $\alpha<0,05$ with the $\mathrm{F}$ value amounting to 5.914. This means that there is at least one influential independent variable namely political connection (KP), fixed asset (PPE) as well as company size (SIZE).

Table 3 shows that the corporate governance variable (TK) has a significant value of significance amounting to $0.307>0.05$. This result indicates that the corporate variable does not affect tax aggressiveness. Based on the result, it could be concluded that H1 is not supported. The variable of political connection (KP) has a value of significance amounting to $0.031<0.05$ with the coefficient marked as negative. This result indicates that the variable of political connection has a negative effect on the effective tax rate. The negative coefficient towards ETR means the increase of tax aggressiveness or in other words has a positive effect on tax aggressiveness. Based on such a result, it could be concluded that $\mathrm{H} 2$ is not supported. The control variable that affects the tax aggressiveness in this research is fixed asset as well as company size.

Setyastrini, N. L. P., Subekti, I., \& Prastiwi, A. (2021). Corporate governance and political connection towards the tax aggressiveness of manufacturing companies in Indonesia. International Research Journal of Management, 
Table 3

Results of Regression Model Analysis

\begin{tabular}{lllll}
\hline Variable & Coefficient & T value & Sig & Decision \\
\hline Corporate Governance (CG) & $-0,015$ & $-0,505$ & 0,307 & H1 rejected \\
Political Connection (PC) & $-0,012$ & $-1,866$ & 0,031 & H2 rejected \\
Profitability (ROA) & $-0,079$ & $-0,966$ & 0,168 & \\
Fixed Asset (PPE) & $-0,096$ & $-2,296$ & 0,012 & \\
Company Size (SIZE) & $-0,010$ & $-1,986$ & 0,024 & \\
F & 5,914 & & & \\
Sig F. & 0,000 & & & \\
Adj $R^{2}$ & 0,093 & & & \\
\hline
\end{tabular}

Dependent Variable: ETR

\#Negatively affects ETR means that it positively affects tax aggressiveness

\section{Discussion}

\section{Corporate governance and tax aggressiveness}

This research indicates that $\mathrm{H} 1$ is not supported meaning that corporate governance does not affect the tax aggressiveness. This research outcome is in line with the research conducted by Wahab \& Holland (2012), as well as Pratiwi et al. (2019). Public companies implement governance not to prevent tax aggressiveness, but rather to meet the recommendations as required by the Financial Services Authority through Circular Letter of the Financial Services Authority Number 32/SEOJK.04/2015. The sample companies in this research have also implemented proper corporate governance. This could be observed from the average observation value of the corporate governance amounting to 0.70 or it has implemented at least 18 out of 25 recommendations pursuant to the Circular Letter of the Financial Services Authority Number 32/SEOJK.04/2015.

\section{Political connection and tax aggressiveness}

The outcome of this research does not support H2. Based on the discussion on the previous hypothesis testing, it was found that the political connection possessed by companies increase their taxing aggressiveness. The outcome of this research is in line with the research conducted by Sudibyo \& Jianfu (2016) and Hidayati \& Diyanty (2018). Companies with political connections create lower chances for the companies to be inspected, face lower expectations to be transparent well as receiving access to information relating to the taxing regulation changes in the future thus making the companies more confident to conduct high-risk measures such as tax aggressiveness (Faccio, 2006; Hillman et al., 2009).

\section{Discussion on the control variable}

The influential control variables in this research are the fixed assets and company size. The fixed asset variable negatively affects the ETR or positively affects the tax aggressiveness. Such research outcome is in line with the research by Hidayati \& Diyanty (2018) and Lestari et al., (2019). Companies carry out tax aggressiveness through fixed assets by charging higher depreciation for tax purposes. Company size negatively impacts the ETR or positively impacts the tax aggressiveness. This research is in line with the research conducted by Puspita \& Febrianti (2017) and Swingly \& Sukartha (2015). Larger companies will have more resources to be involved in tax aggressiveness activities.

\section{Conclusion}

According to the hypothesis testing and the research discussion on previous sub-chapters, it could be concluded that the governance implemented by the companies does not affect the companies' tax aggressiveness measures. The governance implemented by the companies aims to comply with the regulations from the Financial Services Authority 
as issuer supervisor at Indonesia Stock Exchange. Additionally, the political connection possessed by companies tends to encourage companies to carry out tax aggressiveness measures.

Conflict of interest statement

The authors declared that they have no competing interests.

Statement of authorship

The authors have a responsibility for the conception and design of the study. The authors have approved the final article.

Acknowledgments

We are grateful to two anonymous reviewers for their valuable comments on the earlier version of this paper.

Setyastrini, N. L. P., Subekti, I., \& Prastiwi, A. (2021). Corporate governance and political connection towards the tax aggressiveness of manufacturing companies in Indonesia. International Research Journal of Management,

IT and Social Sciences, 8(1), 102-109. https://doi.org/10.21744/irjmis.v8n1.1118 


\section{References}

Adhikari, A., Derashid, C., \& Zhang, H. (2006). Public policy, political connections, and effective tax rates: Longitudinal evidence from Malaysia. Journal of Accounting and Public policy, 25(5), 574-595. https://doi.org/10.1016/j.jaccpubpol.2006.07.001

Anggraeni, R. (2018). Pengaruh Koneksi Politik Terhadap Tax Aggressiveness (Studi Empiris: Perusahaan Manufaktur yang Terdaftar di Bursa Efek Indonesia Tahun 2014-2017). Jurnal Akuntansi, 6(3).

Armour, J., Hansmann, H., \& Kraakman, R. (2009). Agency problems, legal strategies, and enforcement.

Bawazier, F. (2018). Reformasi Pajak di Indonesia Tax Reform In Indonesia. Jurnal Legislasi Indonesia, 8(1), 1-28.

Chan, K. H., Mo, P. L., \& Zhou, A. Y. (2013). Government ownership, corporate governance and tax aggressiveness: evidence from China. Accounting \& Finance, 53(4), 1029-1051.

Claessens, S., Djankov, S., Fan, J. P., \& Lang, L. H. (2002). Disentangling the incentive and entrenchment effects of large shareholdings. The journal of finance, 57(6), 2741-2771.

Desai, M. A., \& Dharmapala, D. (2006). Corporate tax avoidance and high-powered incentives. Journal of financial Economics, 79(1), 145-179. https://doi.org/10.1016/j.jfineco.2005.02.002

Faccio, M. (2006). Politically connected firms. American economic review, 96(1), 369-386.

Fisman, R. (2001). Estimating the value of political connections. American economic review, 91(4), 1095-1102.

Gupta, S., \& Newberry, K. (1997). Determinants of the variability in corporate effective tax rates: Evidence from longitudinal data. Journal of accounting and public policy, 16(1), 1-34. https://doi.org/10.1016/S02784254(96)00055-5

Hidayati, W., \& Diyanty, V. (2018). Pengaruh moderasi koneksi politik terhadap kepemilikan keluarga dan agresivitas pajak. Jurnal Akuntansi dan Auditing Indonesia, 22(1), 46-60.

Hillman, A. J., Withers, M. C., \& Collins, B. J. (2009). Resource dependence theory: A review. Journal of management, 35(6), 1404-1427.

Jensen, M. C., \& Meckling, W. H. (1976). Theory of the firm: Managerial behavior, agency costs and ownership structure. Journal of financial economics, 3(4), 305-360. https://doi.org/10.1016/0304-405X(76)90026-X

Kartika, H. (2019). Tax Justice Laporkan Bentoel lakukan Penghindaran Pajak, Indonesia Rugi US\$ 14 Juta.

Kim, C., \& Zhang, L. (2016). Corporate political connections and tax aggressiveness. Contemporary Accounting Research, 33(1), 78-114.

Kim, I. J., Eppler-Kim, J., Kim, W. S., \& Byun, S. J. (2010). Foreign investors and corporate governance in Korea. Pacific-Basin Finance Journal, 18(4), 390-402. https://doi.org/10.1016/j.pacfin.2010.04.002

Landry, S., Deslandes, M., \& Fortin, A. (2013). Tax aggressiveness, corporate social responsibility, and ownership structure. Journal of Accounting, Ethics \& Public Policy, 14(3), 611-645.

Lestari, G. A. W., \& Putri, I. A. D. (2017). Pengaruh corporate governance, koneksi politik, dan leverage terhadap penghindaran pajak. E-Jurnal Akuntansi Universitas Udayana, 18(3), 2028-2054.

Lestari, P. A. S., Pratomo, D., \& Asalam, A. G. (2019). Pengaruh Koneksi Politik dan Capital Intensity Terhadap Agresivitas Pajak. Jurnal ASET (Akuntansi Riset), 11(1), 41-54.

Lietz, G. M. (2013). Tax avoidance vs. tax aggressiveness: A unifying conceptual framework. Tax Aggressiveness: A Unifying Conceptual Framework.

Mahenthiran, S., \& Kasipillai, J. (2012). Influence of ownership structure and corporate governance on effective tax rates and tax planning: Malaysian evidence. Austl. Tax F., 27, 941.

Margaret, M., Lynch, L. J., Rego, S. O., \& Rego, S. O. (2009). Tax Reporting Aggressiveness to Aggressive and Its Relation Financial Reporting University of Virginia. Accounting Review, 84(2), 467-496.

OECD. (2015). Glosarry of Statistical Terms: Corporate Governance.

Pratiwi, N. P. S. D. R., Subekti, I., \& Rahman, A. F. (2019). The effect of corporate governance and audit quality on tax aggressiveness with family ownership as the moderating variable.

Puspita, D., \& Febrianti, M. (2017). Faktor-faktor yang memengaruhi penghindaran pajak pada perusahaan manufaktur di bursa efek Indonesia. Jurnal Bisnis dan Akuntansi, 19(1), 38-46.

Ramantha, I. W. (2020). Fraud pentagon theory in detecting financial perception of financial reporting with good corporate governance as moderator variable. International research journal of management, IT and social sciences, 7(1), 84-94.

Richardson, G., Taylor, G., \& Wright, C. S. (2014). Corporate profiling of tax-malfeasance: A theoretical and empirical assessment of tax-audited Australian firms. eJTR, 12, 359.

Sudibyo, Y. A., \& Jianfu, S. (2016). Political connections, state owned enterprises and tax avoidance: An evidence from Indonesia. Corporate Ownership and Control, 13(3), 1-6. 
Sutrisno, T., Saraswati, E., \& Purnomosidhi, B. (2019). The effect of related party transactions on firm performance: the moderating role of political connection in indonesian banking. Business: Theory and Practice, 20, 81-92.

Swingly, C., \& Sukartha, I. M. (2015). Pengaruh karakter eksekutif, komite audit, ukuran perusahaan, leverage dan sales growth pada tax avoidance. E-Jurnal Akuntansi Universitas Udayana, 10(1), 47-62.

Taylor, G., \& Richardson, G. (2013). The determinants of thinly capitalized tax avoidance structures: Evidence from Australian firms. Journal of International Accounting, Auditing and Taxation, 22(1), 12-25. https://doi.org/10.1016/j.intaccaudtax.2013.02.005

Wahab, N. S. A., \& Holland, K. (2012). Tax planning, corporate governance and equity value. The British Accounting Review, 44(2), 111-124. https://doi.org/10.1016/j.bar.2012.03.005

Wicaksono, A. P. N. (2017). Koneksi politik dan aggresivitas pajak: Fenomena di indonesia. Akuntabilitas: Jurnal Ilmu Akuntansi, 10(1), 167-180.

Wong, W. Y., \& Hooy, C. W. (2018). Do types of political connection affect firm performance differently?. PacificBasin Finance Journal, 51, 297-317. https://doi.org/10.1016/j.pacfin.2018.08.009

Zhang, H., Li, W., \& Jian, M. (2012). How does state ownership affect tax avoidance? Evidence from China. Singapore Management University, School of Accountancy, 13-18.

Zheng, S. (2017). Can corporate diversification induce more tax avoidance?. Journal of Multinational Financial Management, 41, 47-60. https://doi.org/10.1016/j.mulfin.2017.05.008

Setyastrini, N. L. P., Subekti, I., \& Prastiwi, A. (2021). Corporate governance and political connection towards the tax aggressiveness of manufacturing companies in Indonesia. International Research Journal of Management, IT and Social Sciences, 8(1), 102-109. https://doi.org/10.21744/irjmis.v8n1.1118 